\title{
Hatching Characteristics and Growth Performance of Eggs with Different Egg Shapes
}

http://dx.doi.org/10.1590/1516-635×1801001-008

-Author(s)

Alasahan $S^{\prime}$
Copur AG"

Mustafa Kemal University, Faculty of Veterinary Medicine, Department of Animal Breeding, Hatay, Turkey

" Mustafa Kemal University, Faculty of Agriculture, Department of Animal Science, Hatay, Turkey

\section{-Mail Address}

Corresponding author e-mail address Gulsen Copur Akpinar

Mustafa Kemal University, Agriculture Faculty, Animal Science Department -

Hatay - Turkey - 31034.

Phone: (+90) 3262455845

Email: gulsenankara@gmail.com

\section{EKeywords}

Egg shape index, hatchability of fertile eggs, growth performance, carcass traits.

\section{ABSTRACT}

This study was carried out to identify the effect of the egg shape index on the hatchability, performance, and carcass yield of Japanese quails (Coturnix coturnix Japonica). Eggs were incubated in three groups, according to three different egg shape index (SI) values (Group SI-I: 70.00-73.85\%, Group SI-II: 73.86-77.71\% and Group SI-III: 77.72$81.57 \%)$. Unhatched eggs weight loss (HEWL) was correlated with the egg shape index groups (SI-I: $18.51 \%$, SI-II: $13.34 \%$ and SI-III: 13.96\%; $\mathrm{p}<0.01)$, but not with the initial unhatched egg weight (HIEW), hatched egg weight (HEW), or eggshell weight of unhatched eggs (HSW) $(p>0.05)$. The live weight of female and male chicks hatched from SII, SI-II, and SI-III egg shape index groups were compared at weeks 4 (female/male: 249.12/237.77, 244.69/236.35, and 241.52/229.72 g, respectively) and 5 (female/male:304.89/272.42, 295.76/274.34, and $285.42 / 271.29 \mathrm{~g}$, respectively), and the results showed that females were heavier than males $(p<0.05 ; p<0.01 ; p<0.001$, respectively). The effect of egg shape index on slaughter weight $(p<0.05)$, left leg weight $(p<0.05)$, liver weight $(p<0.01)$ and liver rate $(p<0.01)$ was significant. Females were heavier at slaughter than males in the egg shape index groups SI-I $(p<0.05)$, SI-II $(p<0.05)$, and SI-III (p>0.05) (female/male: $296.87 / 283.80,287.95 / 278.00$ and $283.86 / 278.10 \mathrm{~g}$, respectively). Males presented higher carcass yield in SI-I $(p>0.05)$, SI-II $(p<0.01)$ and SI-III $(p<0.05) \quad$ (female/male: 74.40/75.92, 74.50/76.44 and $74.80 / 76.42 \%$ ) groups than females. Egg shape index had no effect on initial egg weight (IEW), shell blunt end weight (SBW), chick weight, shank length, growth performance or carcass traits, but egg shape indexwas correlated with egg length, egg width, and hatchability of fertile eggs $(p<0.05)$.

\section{INTRODUCTION}

Several studies have been conducted to investigate the effect of egg quality characteristics on hatching results (Salad Uddin et al., 1994; Narushin etal., 2002; Ghodsi etal., 2010; Lotfietal., 2011; King'ori, 2011; Peruzzi et al., 2012;Dudusola, 2013). Several characteristics, including egg weight, eggshell thickness, eggshell pore characteristics, egg shape index, and the consistency of the egg content bear importance for embryonic development and the achievement of satisfactory hatching results. Eggs presenting average physical characteristics are able to meet most of the embryo requirements throughout its development (Narushin \& Romanov, 2002).

Egg shape depends on the anatomical structure of the hen, particularly of the oviduct, internal organ distribution, and shape of the pelvic bones (King'ori, 2012). The egg shape index is the ratio between maximum egg width with maximum egg length (Narushin \& Romanov, 2002), and represents a numeric value of egg shape. 
Many researchers (Farooq et al., 2001; Harun et al., 2001; Narushin \& Romanov, 2002; King'ori, 2011) have suggested that the hatching performance achieved when normal-shaped eggs are laid is greater than that achieved with abnormally-shaped eggs. This is attributed to the change in the axial location of the embryo in normal-shaped eggs during the advanced stages of embryonic development (Ainsworth et al., 2010). In chicken eggs, on day 14 of the incubation period, the head of the embryo moves towards the blunt end of the egg and the embryo acquires a position parallel to the egg axis.

Both hatchling quality and chick weight influence subsequent growth performance. Several studies have been carried out to determine the factors that influence chick hatching weight (Willams, 1994; Khurshid et al., 2003; Seker et al., 2004; Caglayan et al., 2009; Fidan et al., 2012). The correlation between egg shape index and hatching weight was reported to be not statistically significant $(p<0.24)$ (Sahin et al., 2009). On the other hand, Sharma \& Vohra (1980) and Senapati et al. (1996) observed that the hatchability of fertile eggs was negatively correlated with egg shape index in quails. Subsequent research suggested that the egg shape index has no impact on hatchability (Baspinar et al., 1997; Kul \& Seker, 2004; Turkyilmaz et al., 2005; Yilmaz \& Caglayan, 2008; Sari et al., 2010; Copur et al., 2010; Lofti et al., 2011), but it is associated with increased mortality rates during early and late embryonic development (Turkyilmaz et al., 2005).

The average egg shape index values of Japanese quail eggs (Coturnix coturnix japonica) were determined by Gonzalez (1995) as 78.12\%, by Esen \& Ozcelik (2002) as $80 \%$, by Ozcelik, (2002) as $79.57 \%$, by Aktan (2004) as $78.28 \%$, by Sezer (2007) as $79.12 \%$, by Alkan et al. (2010) as $76.80 \%$, by Dudusola (2010) as $78.93 \%$, by Nowaczewski et al. $(2010)$ as $79.2 \%$, by Kumaril et al. (2008) as 79.57\%, by Mudhar Abd Salman Abu Tabeekh (2011) as 79.59\%, by Sarı et al. (2012) as $78.8 \%$, byAbd El-Samee et al. (2012) as 78.42\%, and by Zita et al. (2013) as $77.85 \%$.

The present study aimed at evaluating the effects of egg shape index on hatching parameters, growth performance, and carcass characteristics of Japanese quails.

\section{MATERIALS AND METHOD}

\section{Assessment of Hatching Parameters}

Eggs were collected during a three-day-period on a private farm. After transference to the incubation unit, the eggs were examined macroscopically. By means of visual inspection, cracked and broken eggs were excluded from the study material. A total of 512 eggs were obtained from 16-wk-old Japanese quails (Coturnix coturnix japonica), which reached 95\% egg production.

The hatching eggs were individually numbered and weighed using a precision scale with an accuracy of $0.01 \mathrm{~g}$. Egg length and width were measured using a caliper, and used for the calculation of the egg shape index $(\mathrm{SI}=$ width/length $\times 100)$, according to Panda (1996). Eggs were classified according to egg shape index values, and the class interval of the data was determined as described below.

Class interval $=[$ (highest value-lowest value) / desired number of classes]

Using the class interval calculated according to the formula given above, eggs were allocated into three groups according to their egg shape index values, namely Group SI-I (egg shape index: 70.00-73.85\%), Group SI-II (egg shape index: 73.86-77.71\%), and Group SI-III (egg shape index: 77.72-81.57\%).

The numbers of eggs placed into the setter from Groups SI-I, SI-II, and SI-III were 148, 252, and 112, respectively. After egg shape index determination, eggs from each treatment group were placed randomly into trays in triple layers. Temperature and relative humidity $(\mathrm{RH})$ were set at $37.5^{\circ} \mathrm{C}$ and $55-60 \%$, respectively, during the first 15 days of the incubation period and at $37.2^{\circ} \mathrm{C}$ and $65-70 \%$, respectively, during the hatching period. Prior to transference to the hatcher, all eggs belonging to each egg shape index group were labeled and placed on hatching trays.

The eggs that did not hatch at the end of the incubation period were broken out for macroscopic inspection to determine early embryonic mortality (between days 0-7 of the incubation period), intermediate embryonic mortality (between days 8-14 of the incubation period), or late embryonic mortality (between days 15-17 of the incubation period and at time of pipping) (Taha, 2011). Hatching results were calculated according to the formulae given below.

Fertility rate $(F R, \%)=$ (number of fertile eggs / number of set eggs) $\times 100$

Hatchability of set eggs $(H R, \%)=$ (number of hatched chicks / number of set eggs) x 100

Hatchability of fertile eggs (HRF\%) $=$ (number of hatched chicks / number of fertile eggs) $\times 100$

Rate of early embryonic mortality $(\mathrm{EEM}, \%)=$ (number of early embryonic mortalities/ total number of fertile eggs) $\times 100$ 
Rate of middle embryonic mortality $(\mathrm{MEM}, \%)=$ (number of mid-embryonic mortalities / total number of fertile eggs) $\times 100$

Rate of late embryonic mortality $($ LEM, \% $)=$ (number of late embryonic mortalities / total number of fertile eggs) $\times 100$

\section{Growth Performance}

After hatching, each chick that hatched in all egg shape index groups was identified using a wing bands, weighed, and the right and left shank lengths were measured. Growth performance was determined using 70, 71, and 66 chicks from Groups SI-I (70.00$73.85 \%)$ SI-II (73.86-77.71\%) and SI-III (77.72$81.57 \%)$, respectively, distributed in four replicates each.

The quails were fed a commercial broiler grower feed containing $22 \%$ crude protein and $3000 \mathrm{kcal}$ energy/kg for five weeks. Feed and water were provided ad libitum. Quails were individually weighed, using a precision balance with $0.01 \mathrm{~g}$ accuracy on a weekly basis for the determination of weekly body weight. Quails were sexed at three weeks of age, according to the appearance of the breast feathers (feather sexing).

At the end of the five weeks of the rearing period, 32 birds per group (16 males and 16 females), totaling 96 birds, were sacrificed to determine carcass weight (with and without internal organs), as well as breast, right and left legs, heart, liver, empty gizzard, and intestine weights. These data were used to calculate the following parameters, according to the formulae given below.

Feather +head + feet weight $(\mathrm{g})=$ (slaughter weight - carcass weight with internal organs)

Feather + head + feet yield $(\%)=($ feather-head-feet weight / slaughter weight) $\times 100$

Neck + back + wing weight $(\mathrm{g})=$ (carcass weight (breast weight + left and right leg weight))

Carcass yield $(\%)=$ (carcass weight / slaughter weight) $\times 100$

Carcass parts yield:

Breast yield $(\%)=$ (breast weight $/$ carcass weight) $\times 100$

Right leg yield $(\%)=$ (right leg weight $/$ carcass weight) $\times 100$

Left leg yield $(\%)=$ (left leg weight / carcass weight) $x 100$
Neck + back + wing yield $(\%)=($ neck-back-wing weight / carcass weight) $\times 100$ 100

Heart yield $(\%)=($ heart weight $/$ carcass weight $) \times$ 100

Liver yield $(\%)=$ (liver weight $/$ carcass weight $) x$

Gizzard yield $(\%)=$ (gizzard weight $/$ carcass weight $)$ $x 100$

Intestine yield $(\%)=$ (intestine weight / carcass weight) $\times 100$

\section{Data Assessment and Statistical Analysis}

Hatching parameter data of the egg shape index groups were analyzed using the Chi-square test. Data pertaining to all of the other hatching characteristics investigated were analyzed by one-way analysis of variance (ANOVA). Duncan's multiple comparison test was used to compare means. Within each group, carcass data of male and female animals were analyzed using the t-test. Statistical analyses were performed using the SPSS software package (Version 12).

\section{RESULTS}

\section{Hatching Parameters}

Egg weight, length and width mean values are presented in Table 1.

Table 1 - Hatching eggs characteristics.

\begin{tabular}{lcccc}
\hline Egg shape index groups & $\mathrm{n}$ & $\begin{array}{c}\text { Initial Egg } \\
\text { Weight }(\mathrm{g})\end{array}$ & $\begin{array}{c}\text { Egg Length } \\
(\mathrm{mm})\end{array}$ & $\begin{array}{c}\text { Egg Width } \\
(\mathrm{mm})\end{array}$ \\
\hline SIII (70.00-73.85\%) & 148 & 12.84 & $34.34^{\mathrm{a}}$ & $24.82^{\mathrm{c}}$ \\
\hline SI-II (73.86-77.71\%) & 252 & 12.77 & $33.39^{\mathrm{b}}$ & $25.26^{\mathrm{b}}$ \\
\hline SI-III (77.72-81.57\%) & 112 & 12.60 & $32.34^{\mathrm{c}}$ & $25.61^{\mathrm{a}}$ \\
\hline General & 512 & 12.75 & 33.44 & 25.21 \\
\hline & F & 2.805 & 131.203 & 45.647 \\
\hline & P & 0.061 & 0.000 & 0.000 \\
\hline
\end{tabular}

$a, b, c$ : Means followed by different superscripts in the same column are statistically different $(p<0.001)$.

The egg length and egg width differences among egg shape index groups were statistically significant $(p<0.001)$. Initial egg weights were not different among between the egg shape index groups.

The parameters of the eggs that did not hatch at the end of the incubation period are summarized in Table 2 . Egg weight was not statistically different $(p<0.05)$ among the egg shape index groups. Egg weight loss during the incubation period was greater in Group SI-I $(18.51 \%)$ than the other groups $(p<0.01)$. 
Table 2 - Parameters of the unhatched eggs according to egg shape index.

\begin{tabular}{lccccc}
\hline \multirow{2}{*}{$\begin{array}{l}\text { Egg shape index } \\
\text { groups (\%) }\end{array}$} & $\mathrm{n}$ & \multicolumn{4}{c}{ Parameters } \\
\cline { 3 - 6 } & & HIEW (g) & HEW (g) & HEWL (\%) & HSW (g) \\
\hline SI-I (70.00-73.85) & 52 & 12.96 & $10.53^{\mathrm{b}}$ & $18.51^{\mathrm{a}}$ & 1.06 \\
\hline SI-II (73.86-77.71) & 54 & 12.94 & $11.22^{\mathrm{ab}}$ & $13.34^{\mathrm{b}}$ & 1.08 \\
\hline SI-III (77.72-81.57) & 26 & 12.44 & $10.67^{\mathrm{b}}$ & $13.96^{\mathrm{b}}$ & 1.04 \\
\hline General & 132 & 12.85 & 10.84 & 15.50 & 1.06 \\
\hline & $\mathrm{F}$ & 2.377 & 4.401 & 5.905 & 1.526 \\
\hline & $\mathrm{p}$ & 0.097 & 0.014 & 0.004 & 0.221 \\
\hline
\end{tabular}

$a$, b: Means followed by different superscripts in the same column are statistically different $(p<0.05 ; p<0.01)$; HIEW: initial egg weight of unhatched eggs; HEW: egg weight of unhatched eggs after hatch; HEWL: egg weight loss of unhatched eggs; HSW: eggshell weight of unhatched eggs.

Hatched eggs and chick parameter results are presented in Table 3, according to the egg shape index groups. Chick hatching weight and shank length, and egg and eggshell weights were not different among the egg shape index groups ( $p>0.05)$.

Table 3 - Hatched egg and chick parameter results according to egg shape index groups.

\begin{tabular}{|c|c|c|c|c|c|c|c|}
\hline \multirow{2}{*}{$\begin{array}{c}\text { Egg shape } \\
\text { index groups } \\
(\%)\end{array}$} & \multirow[b]{2}{*}{$\mathrm{n}$} & \multicolumn{6}{|c|}{ Parameters } \\
\hline & & $\begin{array}{l}\text { IEW } \\
(\mathrm{g})\end{array}$ & $\begin{array}{l}\text { SBW } \\
\text { (g) }\end{array}$ & $\begin{array}{l}\text { SPW + } \\
\text { SEW (g) }\end{array}$ & $\begin{array}{l}C W \\
\text { (g) }\end{array}$ & $\begin{array}{l}\text { CRSL } \\
(\mathrm{mm})\end{array}$ & $\begin{array}{l}\mathrm{CLSL} \\
(\mathrm{mm})\end{array}$ \\
\hline $\begin{array}{c}\text { SI-I } \\
(70.00-73.85)\end{array}$ & 96 & 12.78 & 0.20 & 1.03 & 9.11 & 14.72 & 14.42 \\
\hline $\begin{array}{c}\text { SI-II } \\
(73.86-77.71) \\
\end{array}$ & 198 & 12.72 & 0.21 & 1.01 & 9.08 & 14.67 & 14.47 \\
\hline $\begin{array}{c}\text { SI-III } \\
(77.72-81.57)\end{array}$ & 86 & 12.64 & 0.20 & 1.00 & 9.12 & 14.67 & 14.44 \\
\hline \multirow[t]{3}{*}{ General } & 380 & 12.72 & 0.20 & 1.02 & 9.10 & 14.69 & 14.45 \\
\hline & $\mathrm{F}$ & 0.737 & 1.199 & 0.650 & 0.089 & 0.164 & 0.141 \\
\hline & $p$ & 0.479 & 0.303 & 0.523 & 0.915 & 0.849 & 0.869 \\
\hline
\end{tabular}

IEW: initial egg weight, SBW: shell blunt end weight, SPW: shell pointed end weight, SEW: shell equatorial weight, CW: Chick weight, CRSL: chick right shank length, CLSL: chick left shank length.
The effects of egg shape index on hatching parameters are presented in Table 4. The egg shape index affected the hatchability of fertile eggs $(p<0.01)$, hatchability rate $(p<0.01)$, and early embryonic mortality rate $(p<0.05)$, but had no effect on intermediate and late embryonic mortality ( $p>0.05$ ).

Table 4 - The effect of egg shape index on hatching parameters (\%).

\begin{tabular}{|c|c|c|c|c|c|c|}
\hline \multirow{2}{*}{$\begin{array}{c}\text { Egg shape } \\
\text { index groups } \\
(\%)\end{array}$} & \multicolumn{3}{|c|}{ Hatching Results } & \multicolumn{3}{|c|}{$\begin{array}{l}\text { Embryonic Death } \\
\text { in Fertile Eggs }\end{array}$} \\
\hline & FR & HRF & $H R$ & EEM & IEM & LEM \\
\hline $\begin{array}{c}\text { SI-I } \\
(70.00-73.85)\end{array}$ & 91.89 & $70.59^{b}$ & $64.87^{b}$ & $16.91^{\mathrm{a}}$ & 5.88 & 6.62 \\
\hline $\begin{array}{c}\text { SI-II } \\
(73.86-77.71)\end{array}$ & 92.86 & $84.62^{a}$ & $78.57^{a}$ & $8.12^{\mathrm{b}}$ & 3.42 & 3.85 \\
\hline $\begin{array}{c}\text { SI-III } \\
(77.72-81.57)\end{array}$ & 92.86 & $82.69^{a}$ & $76.79^{a}$ & $8.65^{a b}$ & 1.92 & 6.73 \\
\hline$X^{2}$ Value & 0.143 & 11.178 & 9.648 & 7.540 & 2.710 & 1.888 \\
\hline$p$ Value & 0.931 & 0.004 & 0.008 & 0.023 & 0.258 & 0.389 \\
\hline
\end{tabular}

a, b: means followed by different superscripts in the same column are statistically different $(p<0.05 ; p<0.01)$; FR: fertility rate, HRF: hatchability rate of fertile eggs, HR: hatchability of set eggs, EEM: early embryonic mortality rate, IEM: intermediate embryonic mortality rate, LEM: late embryonic mortality rate.

\section{Growth Performance}

The growth performance results of males and females are shown in Table 5, according to the egg shape index groups. The effect of the egg shape index on weekly growth performance was not significant ( $p>0.05)$.

Shank length, hatching weight, and body weight of males and females, according toegg shape index groups, are summarized in Table 6.

Table 5 - Effects of egg shape index on body weight during weeks 1-5.

\begin{tabular}{lccccccccc}
\hline $\begin{array}{l}\text { Egg shape index groups } \\
(\%)\end{array}$ & $\mathrm{n}$ & $\begin{array}{l}\text { CRSL } \\
(\mathrm{mm})\end{array}$ & CLSL (mm) & CW (g) & Week 1 (g) & BW Week 2 (g) & BW Week 3 (g) & BW Week 4 (g) & BW Week 5 (g) \\
\hline SI-I (70.00-73.85) & 70 & 14.74 & 14.50 & 9.08 & 42.31 & 101.72 & 175.88 & 242.15 & 284.95 \\
\hline SI-II (73.86-77.71) & 71 & 14.70 & 14.43 & 9.10 & 40.83 & 101.43 & 174.65 & 240.46 & 284.90 \\
\hline SI-III (77.72-81.57) & 66 & 14.72 & 14.52 & 9.12 & 41.67 & 102.49 & 170.98 & 235.62 & 248.35 \\
\hline General & 207 & 14.72 & 14.48 & 9.10 & 41.60 & 101.87 & 173.90 & 239.49 & 282.83 \\
\hline & F & 0.060 & 0.334 & 0.070 & 1.913 & 0.180 & 1.733 & 2.433 & 1.829 \\
\hline & $p$ & 0.941 & 0.716 & 0.932 & 0.150 & 0.835 & 0.179 & 0.090 & 0.163 \\
\hline
\end{tabular}

CW: chick weight, CRSL: chick right shank length, CLSL: chick left shank length, BW: body weight. 
Table 6 - Shank length, hatching weight, and body weight of male and female Japanese quails during weeks 1-5 according to the egg shape index groups.

\begin{tabular}{|c|c|c|c|c|c|c|c|c|c|c|}
\hline \multirow{2}{*}{ Egg shape index groups (\%) } & \multirow{2}{*}{ Sex } & \multirow{2}{*}{$\mathrm{n}$} & \multirow{2}{*}{$\begin{array}{l}\text { CRSL } \\
(\mathrm{mm})\end{array}$} & \multirow{2}{*}{$\begin{array}{l}\text { CLSL } \\
(\mathrm{mm})\end{array}$} & \multirow{2}{*}{$C W(g)$} & \multicolumn{5}{|c|}{$\mathrm{CW}$} \\
\hline & & & & & & Week 1 & Week 2 & Week 3 & Week 4 & Week 5 \\
\hline \multirow{3}{*}{ SI-I (70.00-73.85 } & Female & 27 & 14.86 & 14.70 & 9.23 & 42.07 & 103.38 & 179.42 & 249.12 & 304.89 \\
\hline & Male & 43 & 14.66 & 14.38 & 8.99 & 42.46 & 100.68 & 173.65 & 237.77 & 272.42 \\
\hline & & $P$ & 0.179 & 0.075 & 0.142 & 0.660 & 0.221 & 0.083 & 0.005 & 0.000 \\
\hline \multirow{3}{*}{ SI-II (73.86-77.71) } & Female & 35 & 14.84 & 14.46 & 8.98 & 40.99 & 102.21 & 177.60 & 244.69 & 295.76 \\
\hline & Male & 36 & 14.57 & 14.40 & 9.22 & 40.69 & 100.68 & 171.78 & 236.35 & 274.34 \\
\hline & & $\mathrm{P}$ & 0.072 & 0.704 & 0.085 & 0.813 & 0.562 & 0.119 & 0.034 & 0.000 \\
\hline \multirow{3}{*}{ SI-III (77.72-81.57) } & Female & 33 & 14.63 & 14.47 & 9.13 & 41.93 & 104.32 & 174.49 & 241.52 & 285.42 \\
\hline & Male & 33 & 14.82 & 14.56 & 9.12 & 41.41 & 100.66 & 167.48 & 229.72 & 271.29 \\
\hline & & $P$ & 0.200 & 0.585 & 0.987 & 0.642 & 0.208 & 0.120 & 0.015 & 0.018 \\
\hline
\end{tabular}

CW: chick weight, CRSL: chick right shank length, CLSL: chick left shank length

The body weight difference between females and males was not statistically different during the first three weeks in any of the egg shape index groups; however, in weeks 4 and 5 , females were significantly heavier than males $(p>0.05, p<0.01, p<0.001)$.
The results of the statistical analysis of slaughter weight and carcass traits are given in Table 7.

Slaughter weight, left leg weight, liver weight and liver percentage were significantly different among the egg shape index groups $(p<0.05, p<0.01)$.

Table7 - Slaughter weight and carcass traits of Japanese quails according to egg shape index groups $(n=32)$.

\begin{tabular}{|c|c|c|c|c|c|}
\hline Characteristics & $\begin{array}{c}\text { SI-I } \\
(70.00-73.85 \%)\end{array}$ & $\begin{array}{c}\text { SI-II } \\
(73.86-77.71 \%)\end{array}$ & $\begin{array}{c}\text { SI-III } \\
(77.72-81.57 \%)\end{array}$ & $\mathrm{F}$ & $P$ \\
\hline Body weight before slaughter (g) & $290.33^{a}$ & $283.40^{\mathrm{b}}$ & $280.98^{b}$ & 4.293 & 0.016 \\
\hline Carcass weight (g) & 218.12 & 213.74 & 212.39 & 2.719 & 0.071 \\
\hline Carcass yield (\%) & 75.16 & 75.47 & 75.61 & 0.284 & 0.753 \\
\hline Breast yield (\%) & 35.61 & 36.00 & 35.66 & 0.422 & 0.657 \\
\hline Right leg yield (\%) & 17.92 & 18.04 & 18.11 & 0.296 & 0.744 \\
\hline Left leg yield (\%) & 17.71 & 17.33 & 17.68 & 2.222 & 0.114 \\
\hline Neck-back-wing yield (\%) & 28.77 & 28.62 & 28.55 & 0.111 & 0.895 \\
\hline Heart yield (\%) & 1.37 & 1.35 & 1.34 & 0.237 & 0.789 \\
\hline Liver yield (\%) & $3.74^{\mathrm{a}}$ & $3.18^{b}$ & $3.60^{a}$ & 5.055 & 0.008 \\
\hline Gizzard yield (\%) & 2.57 & 2.56 & 2.69 & 0.923 & 0.401 \\
\hline Intestine yield (\%) & 4.51 & 4.33 & 4.41 & 0.310 & 0.734 \\
\hline Head-feet-feather yield (\%) & 12.21 & 12.35 & 11.90 & 0.741 & 0.479 \\
\hline
\end{tabular}

$a, b$ : Differences between the mean values shown with different superscripts in the same column are statistically significant $(p<0.05, p<0.01)$.

The slaughter and carcass trait differences observed between males and females in the different egg shape index groups are presented in Table 8. In Groups SI-I and SI-II, the slaughter, liver, gizzard, and intestine weights of the females were significantly higher compared with males $(p<0.05, p<0.01, p<0.001)$. In Group SI-III, only the gizzard and intestine weights were significantly higher in females compared with males

Table 8 - Carcass traits of Japanese quails according to sex and egg shape index groups.

\begin{tabular}{|c|c|c|c|c|c|c|c|c|c|}
\hline \multirow[b]{2}{*}{ Characteristics } & \multicolumn{3}{|c|}{ SI-I (70.00-73.85\%) Sex } & \multicolumn{3}{|c|}{ SI-II (73.86-77.71\%) Sex } & \multicolumn{3}{|c|}{ SI-III (77.72-81.57\%) Sex } \\
\hline & $\begin{array}{l}\text { Female } \\
(n=16)\end{array}$ & $\begin{array}{c}\text { Male } \\
(n=16)\end{array}$ & $P$ & $\begin{array}{l}\text { Female } \\
(n=16)\end{array}$ & $\begin{array}{c}\text { Male } \\
(n=16)\end{array}$ & $P$ & $\begin{array}{l}\text { Female } \\
(n=16)\end{array}$ & $\begin{array}{c}\text { Male } \\
(n=16)\end{array}$ & $P$ \\
\hline Breast percentage (\%) & 35.59 & 35.63 & 0.955 & 36.62 & 35.38 & 0.109 & 35.14 & 36.17 & 0.080 \\
\hline Right leg percentage (\%) & 17.82 & 18.01 & 0.568 & 17.98 & 18.10 & 0.794 & 18.38 & 17.85 & 0.087 \\
\hline Left leg percentage (\%) & 17.60 & 17.81 & 0.455 & 17.34 & 17.33 & 0.960 & 17.82 & 17.53 & 0.298 \\
\hline Neck-back-wing percentage (\%) & 28.99 & 28.55 & 0.413 & 28.06 & 29.19 & 0.203 & 28.66 & 28.44 & 0.697 \\
\hline Heart percentage (\%) & 1.33 & 1.41 & 0.225 & 1.38 & 1.31 & 0.345 & 1.34 & 1.34 & 0.953 \\
\hline Liver percentage (\%) & 4.11 & 3.37 & 0.009 & 3.53 & 2.83 & 0.010 & 3.57 & 3.64 & 0.732 \\
\hline Gizzard percentage (\%) & 2.81 & 2.34 & 0.002 & 2.78 & 2.34 & 0.003 & 2.91 & 2.48 & 0.003 \\
\hline Intestine percentage (\%) & 5.03 & 3.99 & 0.001 & 4.70 & 3.96 & 0.023 & 4.82 & 4.00 & 0.006 \\
\hline Head-feet-feather percentage (\%) & 12.26 & 12.15 & 0.824 & 12.51 & 12.19 & 0.562 & 12.35 & 11.45 & 0.125 \\
\hline
\end{tabular}


$(p<0.01)$. Although carcass yield was not different between males and females in Group SI-I ( $p>0.05)$, the differences between sexes was statistically significant in Groups SI-II and SI-III $(p<0.05)$.

\section{DISCUSSION}

In the present study, no effect of the egg shape index was detected on several parameters, including hatching weight, chick shank length and eggshell weight. This result is consistent with previous research reporting that the egg shape index does not affect hatchling weight (Saatci et al., 2005; Yilmaz \& Caglayan, 2008; Lotfi et al., 2011).

However, the results demonstrated that egg shape index influences both hatchability and carcass yield, in contrast to previous research suggesting that the egg shape index does not affect hatchability (Baspinar et al., 1997; Kul \& Seker, 2004; Turkyilmaz et al., 2005; Sari et al., 2010; Lotfi et al., 2011; Taha, 2011). Furthermore, the results showing that egg shape index affects early embryonic death rate do not agree with previous studies suggesting that egg shape index does not have any effect on this parameter (Copur et al., 2010; Sari et al., 2010). These differences may be attributed to different classifications of egg shape indices used among studies. In the present study, the hatchability of fertile eggs was lower in Group SI-I, in comparison with the other egg shape index groups, due to higher early embryonic death. This is attributed to the $18.51 \%$ egg weight loss observed during the incubation period, which is above the optimal egg weight loss. The egg weight loss rates in groups SI-II and SI-III were $13.34 \%$ and $13.96 \%$, respectively, and were close to the optimal rate.

The effect of the egg shape index on the growth performance of Japanese quails during the fiveweek rearing period was not statistically significant. This result was in agreement with previous research (Copur et al., 2010). In the present study, within each egg shape index group, males and females presented significantly different body weights, as measured during the rearing period.

Relative to slaughter weight and carcass traits, only the left leg and liver weights were different among the egg shape index groups $(p<0.05, p<0.01)$. The egg shape index did not have any effect on either carcass weight or on the other carcass parameters investigated. The lack of an effect of the egg shape index on leg length and on slaughter and carcass weights may be interpreted as a consequence of the lack of effect on hatchling weight.

\section{CONCLUSION}

Egg shape index affects the hatchability of set eggs, hatchability of fertile eggs, and early embryonic mortality. There is no influence of egg shape index on embryonic mortalities (middle and late), chick weight, and body weight during 1-5 weeks.

\section{REFERENCES}

Abd El-Samee LD, El-Wardanyl, Nematallah GA, Abo-El-Azab OM. Egg quality, fertility and hatchability of laying quails fed diets supplement with organic zinc, chromium yeast or mannan oligosaccharides. International Journal of Poultry Science 2012;11(3):221-224.

Ainsworth SJ, Stanley RL, Evans DJR. Developmental stages of the Japanese quail. Journal of Anatomy 2010;216:3-15.

Aktan S. Determining some exterior and interior quality traits of quail eggs and phenotypic correlations by digital image analysis. Hayvansal Uretim 2004; 45(1):7-13.

Alkan S, Karabag K, Galic A, Karsli T, Balcıoglu MS. Effects of selection for body weight and egg production on egg quality traits in Japanese quail (Coturnix coturnix japonica) of different lines and relationships between these traits. Journal of The Faculty of Veterinary Medicine, Kafkas University 2010;16(2):239-244.

Baspinar E, Yildiz MA, Ozkan MM, Kavuncu O. The effect of egg weight and egg shape index on hachability in Japanese quail eggs. Turkish Journal of Veterinary and Animal Sciences 1997;21(1):53-56.

Caglayan T, Garip M, Kirikci K, Gunlu A. Effect of egg weight on chick weight, egg weight loss and hatchability in rock partridges (A. graeca). Italian Journal of Animal Science 2009;8:567-574.

Copur G, Baylan M, Canogullari S. Egg weight but egg shape index, determines the hatchability in Japanese quail (Coturnix coturnix japonica). Journal of Animal and Veterinary Advances 2010;9(13):18901895.

Dudusola 1O. Comparative evaluation of internal and external qualities of eggs from quail and guinea fowl. International Research Journal of Plant Science 2010;1(15):112-115.

Dudusola IO. The effect of parental age and egg weight on fertility hatchability and day-old chick weight of Japanese quail (Coturnix coturnix japonica). Standard Research Journal of Agricultural Sciences 2013;1(2):13-16.

Esen A, Ozcelik M. The effect of age of parents, egg weight and egg shape index on hatchability in quails. Firat University Veterinary Journal of Health Sciences 2002; 16(1):11-17.

Farooq M, Durrani FR, Aleem M, Chand N, Muqarrab AK. Egg traits and hatching performance desi, fayumi and rhode island red chicken. Pakistan Journal of Biological Sciences 2001;4(7):909-911.

Fidan ED, Turkyilmaz MK, Nazligul A. The effects of different storage and fumigation lengths on hatchability and hatching weight in Japanese quails (Coturnix coturnix japonica). Journal of Animal and Veterinary Advances 2012;11(9):1400-1404.

Ghodsi MB, Maheri-Sis N, Lotfi A, Abedi AS. Effects of setting eggs small end up on hatchability and embryo mortality in Japanese quail (Coturnix coturnix japonica). Global Veterinaria 2010;4(6):592-594.

González M. Influence of age on physical traits of Japanese quail (Coturnix coturnix japonica) eggs. Ann Zootech 1995;44:307-312. 
Harun MAS, Veeneklaas RJ, Visser GH, Van Kampen M. Artificial incubation of Muscovy duck eggs: why some eggs hatc and others do not. Poultry Science 2001;80:219-224.

Khurshid A, Faroog M, Durrani FR, Sarbiland K, Chand N. Predicting egg weight, shell weight, shell thickness and hatching chick weight of Japanese quails using various egg traits as regressors. International Journal of Poultry Sciences 2003;2(2):164-167.

King'ori AM. Review of the factors that influence egg fertility and hatchabilty in poultry. International Journal of Poultry Science $2011 ; 10(6): 483-492$.

King'ori AM. Poultry egg external characteristics: egg weight, shape and shell colour. Research Journal of Poultry Sciences 2012;5(2):14-17.

Kul S, Seker I. Phenotypic corrolations some external and internal egg quality traits in Japanese quail (Coturnix coturnix japonica). International Journal of Poultry Science 2004;3(6):400-405.

Lotfi A, Shadryar HA, Maheri-Sis N, Abedi AS, Nahand MK. Hatching characterizes of Japanese quail (Coturnix coturnix japonica) eggs with different egg shape indexes. American-Eurasian Journal Agricultural \& Environmental Sciences 2011;10(3):475-477.

Mudhar Abd Salman Abu Tabeekh. Evaluation of some external and internal egg quality traits of quails reared in basrah city. Brazilian Journal Veterinary Research 2011;10(2):78-84.

Narushin VG, Romanov MN. Egg physical characteristics and hatchability. World's Poultry Science Journal 2002;58:297-303.

Narushin VG, Romanov MN, Bogatyr VP. Relationship between preincubation egg parameters and chick weight after hatching in layer breeds. Biosystems Engineering 2002;83(3):373-381.

Nowaczewski S, Kontecka H, Rosiñski A, Koberling S, Koronowski P. Egg quality of japanese quail depends on layer age and storage time. Folia Biologica 2010;58:201-207.

Ozcelik M. The phenotypic correlations among some external and internal quality characteristics in Japanese quail eggs. Veterinary Journal of Ankara University 2002; 49;67-72.

Panda PC. Shape and texture. In textbook on egg and poultry technology. $3^{\text {rd }}$ ed. New Delhi; 1996. p.57.

Peruzzi NJ, Scala NL, Macari M, Furlan RL, Meyer AD, Fernandez-Alarcon MF, Kroetz Neto FL, Souza FA. Fuzzy modelling to predict chicken egg hatchability in commercial hatchery. Poultry Science 2012;91:27102717

Punya KB, Ramesh GB, Gnana PM, Rajasekhar RA. A study on egg quality traits in Japanese quail (Coturnix coturnix japonica). Tamilnadu Journal Veterinary \& Animal Science 2008;4(6):227-231.

Saatci M, Kirmizibayrak T, Aksoy AR, Tilki M. Egg weight, egg shape index and hatching weight and interrelationships among yhese traits in native Turkish geese with different coloured feathers. Turkish Journal of Veterinary and Animal Sciences 2005;29:353-357.
Sahin EH, Sengor E, Yardimci M, Cetingul IS. Relationship between preincubation egg parameters from old breeder hens, egg hatchability and chick weight. Journal of Animal and Veterinary Advances 2009;8(1):115-119.

Salah Uddin M, Paul DC, Huque QME. Effect of egg weight and preincubation holding periods on hatchability of Japanese quail eggs in different seasons. Asian-Australasian Journal of Animal Sciences $1994 ; 7(4): 499-503$

Sari M, Tilki M, Saatci M, Isik S, Onk K. Effect of parental age, egg weight and egg shape index on hatchability traits and liveability in Japanese quail (Coturnix coturnix japonica). Firat University Veterinary Journal of Health Sciences 2010;24(2):93-97.

Sarı M, Isık S, Onk K, Tilki M, Kirmizibayrak T. Effect of layer age and different plumage colors on external and internal egg quality characteristics in Japanese quail (Coturnix coturnix japonica). Archiv fur Geflügelkunde 2012;76(4):254-258

Seker I, Kul S, Bayraktar M. Effects of parental age and hatching egg weight of Japanese quails on hatchability and chick weight. International Journal of Poultry Science 2004; 3(4): 259-265.

Senapati PK, Das K, Mondal KG, Ghatterjee AK.Relationship between egg weight, egg shape index and fertility and hatchability of Japanese quail egg. Environment Ecology 1996;14:574-577.

Sezer M. Heritability of exterior egg quality traits in Japanese quail. Journal of Applied Biological Sciences 2007;1(2):37-40.

Sharma PK, Vohra P. Relationship between egg weight, egg shape index and hatchability of Japanese quail (Coturnix coturnix japonica) eggs. Indian Journal of Poultry Science 1980;15(1):5-10.

Taha AE. Analyzing of quail eggs hatchability, quality, embryonic mortality and malpositions in relation to their shell colors. Online Journal of Animal and Feed Research 2011; 1(6):267-273.

Turkyilmaz MK, Dereli E, Sahin T. Effects of shell thickness, shell porosity, egg shape index and egg weight loss on hatchability in Japanese quail (Coturnix coturnix japonica). Journal of The Faculty of Veterinary Medicine, Kafkas University 2005;11(2):147-150.

Williams TD. Intraspecific variation in egg size and egg composition in birds: Effects on off-spring fitness. Biological Reviews 1994;69(1):1-33.

Yilmaz A, Caglayan T. Egg weight, egg shape index, hatching weight and correlations among these traits in Japanese quail (Coturnix coturnix japonica) with different colored plumages. FIrat University Veterinary Journal of Health Sciences 2008;22(1):5-8

Zita L, Ledvinka Z, Klesalová L. The effect of the age of Japanese quail on certain egg quality traits and their relationships. Veterinarski Arhiv 2013:83(2):223-232. 
